\title{
Functional impairment with minimal macular damage in femtosecond laser plasma injury: case report
}

\author{
Comprometimento funcional com dano macular mínimo em lesão com plasma de laser de femtosegundo: \\ relato de caso
}

\author{
Cristina Freitas ${ }^{1,2}$, Natacha Moreno-Perdomo ${ }^{3}$, Rita Gentil², António M. G. Baptista ${ }^{4}$, António Filipe Macedo ${ }^{4}$
}

\begin{abstract}
A 26 years old female patient was examined twenty-four hours after observing laser-induced plasma formation in a process of nanoparticle production complaining of bilateral central scotoma. The ophthalmologic evaluation included dilated fundus observation, fluorescein angiography, and optical coherence tomography (OCT). In the first assessment, visual acuity was 20/20 in the right eye and 20/25 in the left eye. Ophthalmologic evaluation revealed colour changes in the macular region of both eyes. Optical coherence tomography showed a central interruption of the photoreceptor layer in both eyes and fluorescein angiography was normal. In subsequent appointments acuity was always 20/20 in both eyes. Abnormal optical coherence tomography findings disappeared in less than 5 months, but subjective complaints of scotoma in the left eye remained. Extra care must be taken in this type of experiment by, for example, reducing the time that the retina is directly exposed to the plasma radiation.
\end{abstract}

Keywords: Retina/injuries; Tomography, optical coherence; Scotoma/diagnosis; Fluorescein angiography; Case report

\section{RESUMO}

Uma paciente de 26 anos foi examinada 24 horas após observar a formação de plasma induzido por laser em um processo de produção de nanopartículas, referindo escotoma central bilateral. A avaliação oftalmológica incluiu observação dilatada da retina, angiofluoresceinografia e tomografia de coerência óptica (OCT). Na primeira avaliação, a acuidade de 20/20 no olho direito e 20/25 no olho esquerdo. A avaliação oftalmológica revelou mudanças de coloração da região macular de ambos os ol hos. A tomografia de coerência óptica mostrou uma interrupção central da camada de fotorreceptores em ambos os olhos, e a angiografia fluoresceínica foi normal. Nas consultas subsequentes a acuidade sempre foi $20 / 20$ em ambos os ol hos. Os achados da tomografia de coerência óptica anormais desapareceramem menos de cincomeses, mas as queixas subjetivas de escotoma no olho esquerdo permaneceram. Cuidado extra deve ser tomado para este tipo de experiência, por exemplo, reduzindo o tempo em que a retina é diretamente exposta à radiação de plasma.

Descritores: Retina/lesões; Tomografia de coerência óptica; Escotoma/diagnóstico; angiofluoresceinografia; Lasers; Relato de caso

\section{INTRODUCTION}

Lasers are used in many industries and laboratories. Most applications require special precautions to avoid direct contact of the laser light with the eye. It is known that laser can damage the eye through three different mechanisms: thermal, mechanical and photochemical(1). In all cases the extent of the injury is essentially determined by the pulse duration and by the energy level of the beam ${ }^{(2,3)}$. The final energy of the laser can be influenced by factors such as beam divergence, spatial distribution of the energy and pulse repetition rate $e^{(4,5)}$.

Here we report an accidental retinal burn with a femtosecond laser during laser-induced plasma formation in a process of nanoparticle production. The process consisted of focusing a $1 \mathrm{~W}$, Titanium-Sapphire laser, with a pulse energy of 1 millijoule, wavelength 800 nanometres, pulse repetition rate $1 \mathrm{kHz}$ and pulse duration of 120 fentosecond, in a plasma. Tight focus of high-intensity pulsed lasers generates a strong electrical field that produces a luminescent plasma that is seen as a bright flash of blue-white light and accompanied by a sharp click ${ }^{(6)}$. The health and safety rules determine that protective goggles with optical density 8 (attenuation factor $10^{8}$ ) must be worn to ensure eye protection.

\section{CASE REPORT}

A graduate physics student without any history of eye disease presented to one of the authors complaining of bilateral central scotoma 24 hours after directly observing plasma during nanoparticle production. During nanoparticle production the student was wearing adequate protective goggles. Visual acuity was 20/20 in the right eye and 20/25 in the left eye. During acuity measurement the patient reported the need to move the head and eye slightly away from the letters to avoid a scotoma.

Anterior segment and media were clear in both eyes. Dilated fundus examination revealed bilateral whitish lesions near the fovea, in the left eye more than the right (Figures $1 \mathrm{~A}$ and D). Optical coherence tomography (OCT) was performed (Cirrus HD-OCT, Carl Zeiss Meditec Inc, Dublin, CA), OCT images are shown in figures $1 \mathrm{~B}$ and E. Fluorescein angiography (Figures $1 \mathrm{C}$ and $\mathrm{F}$ ) of both eyes was performed without abnormal findings. A central 10 degrees automated static perimetry was performed (Humphrey Field Analyzer HFA II-i Series, Carl Zeiss Ophthalmic Systems, Inc., Dublin, CA) and was completely normal (images not shown).
Submitted for publication: December 6, 2012

Accepted for publication: August 8, 2013

Study was carried out at University of Minho.

Physician, Life and Health Sciences Research Institute (ICVS), School of Health Sciences, University of Minho, Braga, Portugal; ICVS/3B's - PT Government Associate Laboratory, Braga/Guimarães, Portugal.

2 Physician, Department of Ophthalmology, Hospital de Braga, Braga, Portugal.

${ }_{3}$ Physician, Department of Ophthalmology, Hospital Santa Maria Maior, Barcelos.

${ }^{4} \mathrm{PhD}$, Center of Physics, University of Minho, Minho, Braga Portugal.
Funding: No specific financial support was available for this study

Disclosure of potential conflicts of interest: C.Freitas, None; N.Moreno-Perdomo, None; R.Gentil, None; A.M.G.Baptista, None; A.F.Macedo, None.

Correspondence address: Cristina Freitas. Life and Health Sciences Research Institute (ICVS), School of Health Sciences, University of Minho - Braga, Portugal

E-mail: cristinafreitas83@gmail.com 
In the fourth week of follow-up the patient continued to report scotoma in the left eye only. Visual acuity was 20/20 in both eyes. OCT images, represented in figures $2 \mathrm{~A}$ and $\mathrm{C}$, were different from the first day: the right eye was completely normal and the lesion on the left eye was almost unnoticeable.

At the five month appointment the patient continued to complain about a scotoma in the left eye, but only minimal structural changes were visible on OCT shown in figure $2 \mathrm{~B}$ and $\mathrm{D}$. Ten months latter visual disturbances remained in her left eye, acuity was 20/20 in both eyes and OCT was normal in both eyes (images not shown). As no structural changes were visible to explain the complaint of scotoma in the left eye, subjective macular mapping was performed using microperimetry (Nidek MP1, Padova, Italy). Microperimetry results (Figure 3) revealed a normal retinal sensitivity. During microperimetry the patient complained of something in its vision that "comes and goes and sometimes overlaps with the fixation cross". We believe the retinal image was refreshed by fixational eye movements and any small effect of the lesion was not detected ${ }^{(7)}$.

\section{DISCUSSION}

This case shows that during nanoparticle production using pulsed femtosecond lasers retinal injuries can occur even when the recommended eye protection is used. The symptoms occurred hours after the eyes were exposed to harmful light. The lack of abnormality in the fluorescein angiography indicates that the lesion was not caused by direct action of the laser but, probably, by the laser induced plasma flash ${ }^{(8)}$. A similar case has been reported by Yang et al. ${ }^{(9)}$, as in Yang's report, the injury observed seems to be caused by radiation emitted by the plasma ${ }^{(10)}$. However, unlike in Yang's case, in our case the patient was wearing protective goggles and the lesion was less severe.

We believe that a photochemical process similar to the mechanism of a solar burn caused the retinal damage. As happens in many cases of solar burn, no angiographic abnormalities were found ${ }^{(11,12)}$. Thermal and mechanical processes require absorption of large amounts of energy in a very short period of time, which is not consistent with the case described here ${ }^{(3,13)}$. Also, mechanical processes cause more extensively visible disruption of the surrounding tissues and immediate noticeable changes in vision ${ }^{(3,4,14)}$. Thermal processes are also expected to cause extensive damage because heat spreads away from the primary site of absorption damaging over a large area around $i^{(13)}$. This was not observed in our case. In our patient lesions were well defined and angiography excluded leaking. Other factor that led us to consider a photochemical process was the time between the light exposure and the onset of visual symptoms. As in our patient, in a photochemical process symptoms are expected to occur only hours after the exposure. In these cases damage is normally visible in the outer layers at the central region of the retina ${ }^{(4)}$.

We speculate why the injury happened in the first place. The first OCT we performed, (Figures 1-B and 1-E), revealed damage at
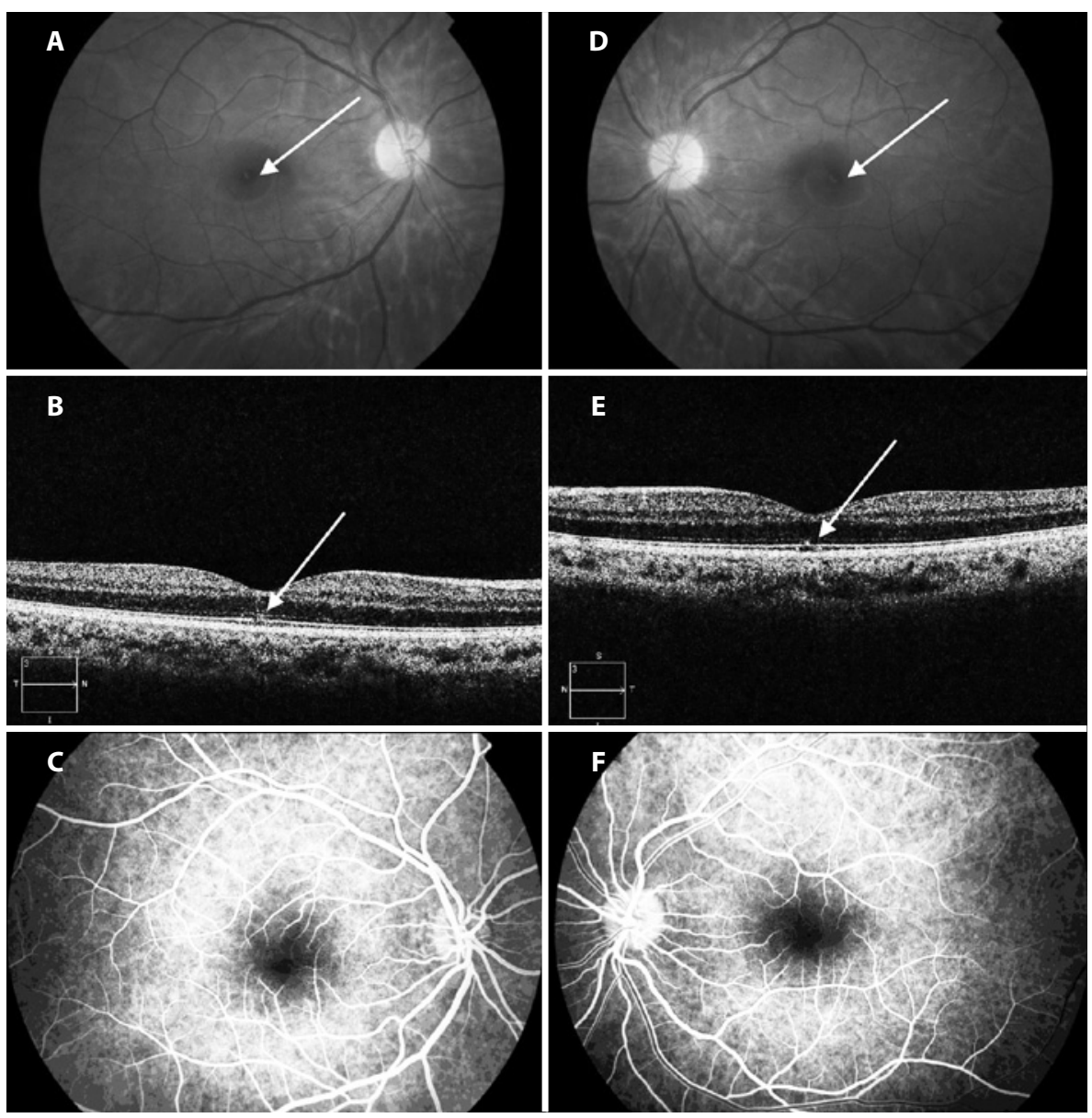

Figure 1. Images of the fundus collected during the first visit of the patient. $A, B$ and $C$ ) Belong to the right eye; $D, E$ and F) Belong to the left eye. Top row: Retinography; small peri-foveal whitish lesions on both eyes; Middle row: OCT images 24 hours after the accident show a central interruption of the photoreceptor layer in both eyes. Bottom row: Fluorescein angiography without abnormal signs. 

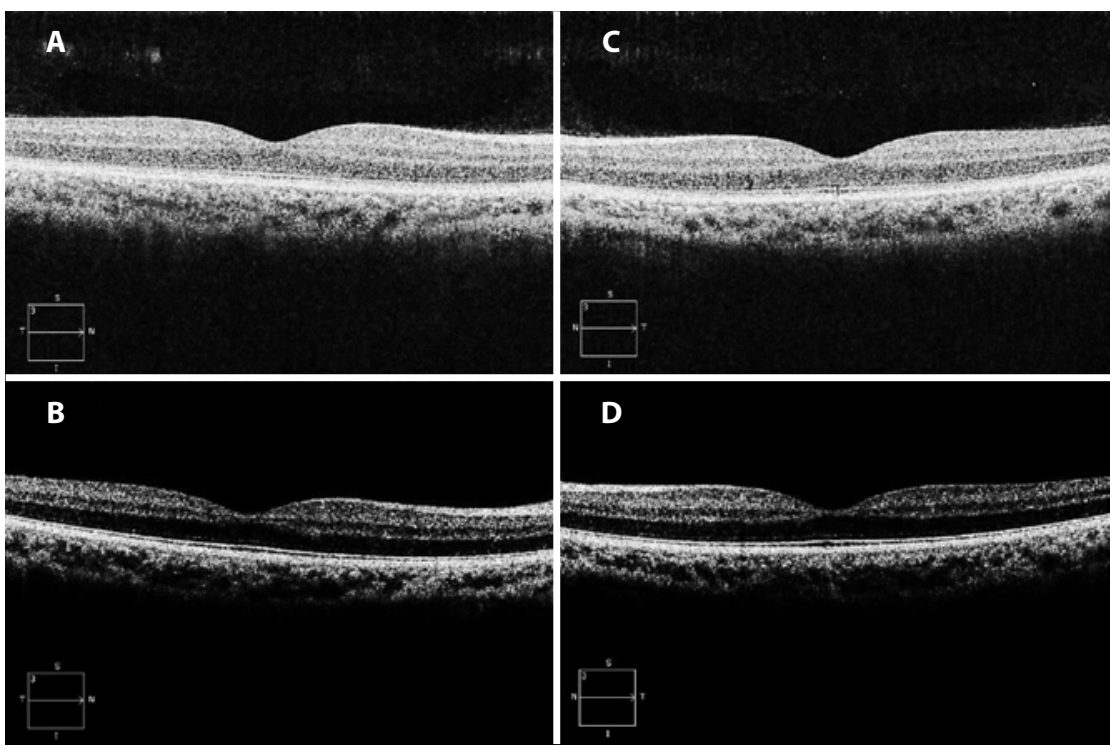

Figure 2. OCT images collected during follow-up visits. A and B) Belong to the right eye; $C$ and D) Belong to the left eye. Top row: four weeks; Bottom row: five months.
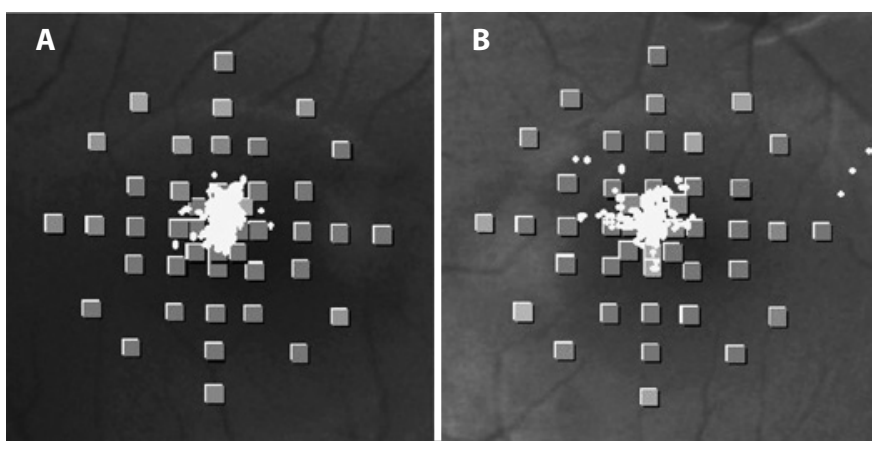

Figure 3. Microperimetry of right $(\mathrm{A})$ and left $(\mathrm{B})$ eye performed ten months after retinal injury. The test consisted of 45 equally separated points in the central $8^{\circ}$ using a Goldmann II stimuli and a 4-2-1 strategy.

the level of the photoreceptors layer. This is coherent with a mild photochemical injury ${ }^{(15)}$. The lesion disappeared progressively and became almost unnoticeable in less than five months as shown in figures $2 \mathrm{~B}$ and $\mathrm{D}$. The literature reports factors such as pigmentation of the retina, the adaptation state of the eye, age of the individual influence the extent of the retinal damage caused by radiation ${ }^{(4,16)}$ Thus, some or all these factors might have interfered with the eye protection provided by goggles.

Momentary exposure to a plasma flash is unlikely to cause retinal damage even without protection ${ }^{(17)}$. Our patient reported to be looking without any concerns to the plasma during extended periods. Thus, we speculate if retinal damage occurred also due to a cumulative effect of a prolonged exposure. It is important to highlight that there are procedures widely used in Ophthalmology such as LASIK flap processing that also use laser-induced plasma formation. Laser-induced plasma is the basic mechanism of action to create corneal resections ${ }^{(18)}$. However, as reported by Yang et al., pulse energies required for femtosecond laser flap creation are few to several microjoule ${ }^{(9)}$ which are of approximately 3 orders of magnitude lower than the laser used here (1 millijoule). Another reason to not be concerned is that LASIK formed plasma moves quite fast inside the corneal stroma during flap creation ${ }^{(18)}$. This ensures only momentary exposure to plasma in each impact site of the retina.
In conclusion, here we report a case in which a patient suffered retinal injuries during nanoparticle production despite wearing adequate protection goggles. Laboratories running these types of experiments should better characterize the radiation emitted by plasmas and should take more effective safety measures to prevent this type of accidents.

\section{REFERENCES}

1. Barkana Y, Belkin M. Laser eye injuries. Surv Ophthalmol. 2000;44(6):459-78.

2. Ham WT Jr, Ruffolo JJ Jr, Mueller HA, Guerry D $3^{\text {rd }}$. The nature of retinal radiation damage: dependence on wavelength, power level and exposure time. Vision Res. 1980; 20(12):1105-11.

3. Marshall J. Thermal and mechanical mechanisms in laser damage to the retina. Invest Ophthalmol. 1970;9(2):97-115.

4. Wu J, Seregard S, Algvere PV. Photochemical damage of the retina. Surv Ophthalmol 2006;51(5):461-81.

5. Vincelette RL, Welch AJ, Thomas RJ, Rockwell BA, Lund DJ. Thermal lensing in ocular media exposed to continuous-wave near-infrared radiation: the 1150-1350-nm region. J Biomed Opt. 2008;13(5):054005.

6. Lubatschowski H. Overview of commercially available femtosecond lasers in refractive surgery. J Refract Surg. 2008;24(1):S102-7.

7. Martinez-Conde S, Macknik SL, Hubel DH. The role of fixational eye movements in visual perception. Nat Rev Neurosci. 2004;5(3):229-40.

8. Birngruber R, Puliafito CA, Gawande A. Femtosecond laser tissue interactions - retinal injury studies. IEEE J Quantum Electron. 1987;23(10):1836-44.

9. Yang $X$, Jiang F, Song Y, Peng C, Sheng S, Li X. Accidental macular injury from prolonged viewing of a plasma flash produced by a femtosecond laser. Ophthalmology. 2010;117(5):972-5.

10. Moseley H, Allan D. Intensity of the flash associated with laser-induced plasma in the eye. Phys Med Biol. 1987;32(9):1159-66.

11. Jorge R, Costa RA, Quirino LS, Paques MW, Calucci D, Cardillo JÁ, et al. Optical coherence tomography findings in patients with late solar retinopathy. Am J Ophthalmol. 2004;137(6):1139-43.

12. Kung YH, Wu TT, Sheu SJ. Subtle solar retinopathy detected by Fourier-domain optical coherence tomography. J Chin Med Assoc. 2010;73(7):396-8.

13. Marshall J, Mellerio J. Laser irradiation of retinal tissue. Br Med Bull. 1970;26(2):156-60.

14. Ham WT Jr, Mueller HA, Goldman Al, Newnam BE, Holland LM, Kuwabara T. Ocular hazard from picosecond pulses of Nd: YAG laser radiation. Science. 1974;185(148):362-3.

15. Moriya M, Baker BN, Williams TP. Progression and reversibility of early light-induced alterations in rat retinal rods. Cell Tissue Res. 1986;246(3):607-21.

16. Youssef PN, Sheibani N, Albert DM. Retinal light toxicity. Eye (Lond). 2011;25(1):1-14.

17. Mainster MA, Stuck BE, Brown J Jr. Assessment of alleged retinal laser injuries. Arch Ophthalmol. 2004;122(8):1210-7.

18. Ratkay-Traub I, Juhasz T, Horvath C, Suarez C, Kiss K, Ferincz I, et al. Ultra-short pulse (femtosecond) laser surgery: initial use in LASIK flap creation. Ophthalmol Clin North Am. 2001;14(2):347-55, viii-ix. 